\title{
Modern trends of development of the world economy and financial competitiveness of enterprises
}

\author{
Nadezhda Volkova $^{1, *}$ and Valeria Shagun ${ }^{1}$ \\ ${ }^{1}$ Saint Petersburg Polytechnic University Peter the Great, 195251, Saint-Petersburg, Russia
}

\begin{abstract}
The article considers modern trends in the development of the global economy, the dynamics of the activity of the domestic economy. The statistical data of the share of loss-making enterprises on the domestic market are analyzed. The importance of competitiveness and financial stability of enterprises in modern conditions is considered, the relationship between competitiveness and financial stability is indicated. The notion of financial competitiveness is formulated. Financial competitiveness is analyzed from the point of view of enterprise management and on the parameters for assessing the financial stability of enterprises. Methods for assessing the financial competitiveness of enterprises have been identified. The primary calculation of financial competitiveness indicators for PJSC "SF Almaz" was carried out based on the selected methods. The analysis of the obtained calculation results is carried out. Methods are proposed to ensure financial competitiveness of Russian companies.
\end{abstract}

Key words: modern trends, competitiveness, economy, finance

\section{Introduction}

In modern conditions, the domestic economy is characterized by a prolonged economic decline in activity, not only at the moment, but also in relation to the previous year, without justifying the forecasts of the Government and the Central Bank. This is due to a number of reasons of external and internal nature, which exert their influence on all spheres of social reproduction. There is a decline in GDP, partial stagnation of unemployment and inflation. According to the Ministry of Economic Development of Russia, the decline in GDP for the first half of the year was $-0.9 \%$ to the corresponding period of 2015 [1]. The main impact on the partial slowdown in the economic recession, according to the Ministry of Economic Development of Russia, was provided by industrial production, transport, and agriculture. Construction and retail trade have a negative impact on the economic situation. These problems can presumably in the near future create a serious threat to macroeconomic stability and sustainable economic growth.

According to Rosstat, the share of enterprises that operate in Russia at a loss in JanuaryMay-May 2016 increased by $0.2 \%$ to $32.2 \%$ compared to the same period in 2015 . The balanced financial result of organizations, that is, the amount of profit less losses, for the

*Corresponding author: nadine_13@mail.ru 
five months amounted to 4.3 trillion rubles. More than 34 thousand organizations earned 5.2 trillion rubles, another 16.3 thousand suffered losses in the amount of 902.4 billion rubles [2]. Figure 1 shows a diagram of the proportion of loss-making enterprises in Russia by industry. The information base for drawing up the chart was provided by the Federal State Statistics Service [2].

The diagram shows that the positive dynamics for the reporting period is represented by enterprises in the spheres of agriculture and hunting (17.4\% were unprofitable), followed by fisheries and fish farming $(20.4 \%)$, retail trade, repair of auto transport and household goods ( $23.2 \%$ ) and construction (32.1\%).

The most unprofitable was the work of enterprises in the sectors of production and distribution of electricity, gas and water (45.5\%), mining (38.6\%), real estate and rent (35.3\%). Last year, the share of unprofitable organizations in the country was $28.1 \%$.

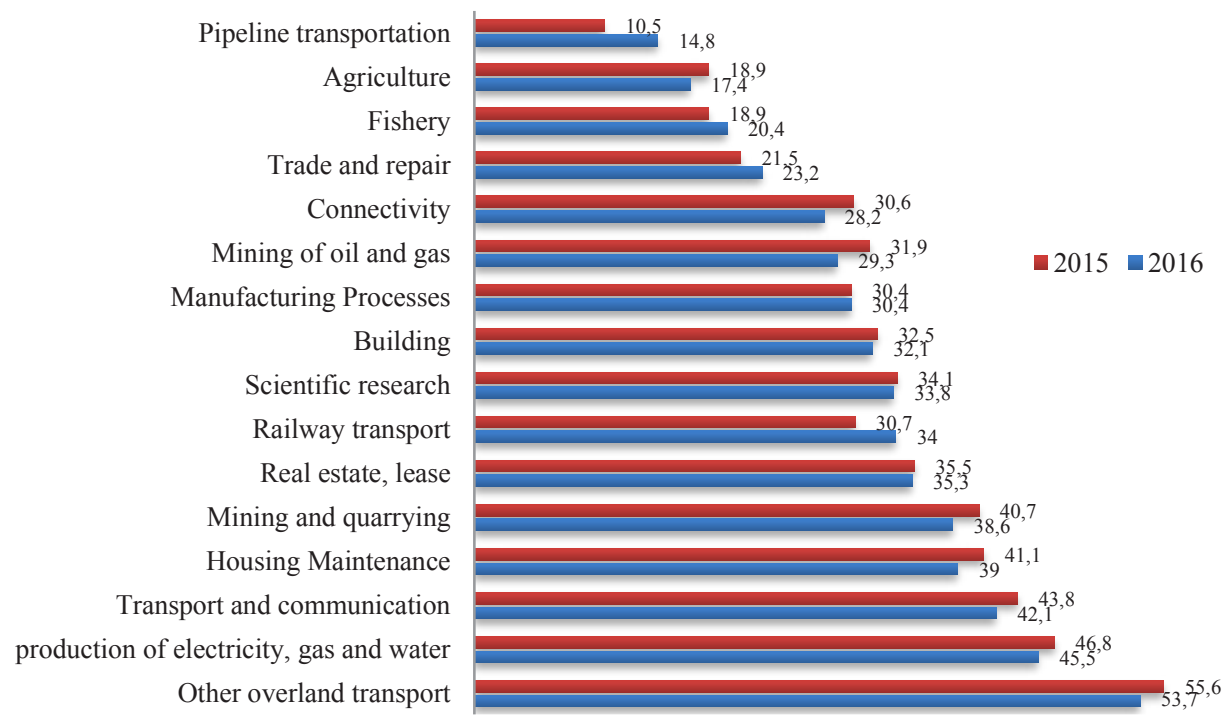

Fig. 1. Share of loss-making enterprises in Russia by industry (\%)

As can be seen from Figure 1, the share of loss-making enterprises is declining quite slowly, but their share is high. This situation is a consequence of the crisis situation in the country and the fact that the enterprises do not match the conditions for the development of the world economy. The growth of the world economy has stabilized at a level of 3.4\% per year, which is well below the average annual growth rate in the last ten-year period, when even taking into account the crisis phenomena of 2008-2009. Growth was higher than $4 \%$ per year [3]. In the context of globalization, this dynamic has had an impact on the Russian economy. A consequence for the domestic economy was the outflow of foreign investment from previously attractive industries, such as the resource-extracting industry, energy, wholesale and retail trade [4]. After the aggravation of the geopolitical situation, many states began to refuse to import Russian oil and gas, switching to other sources of purchasing these resources. This negatively affected the investment attractiveness of the industry, since the profits of these industries mainly depend on oil prices.

The manifestation of the negative effect on the economy on the part of the construction industry is characterized by a high percentage of commercial credit. As a result, expensive loans, the uncertain economic situation in the country and weak demand have an impact on investment in the domestic industry. 
In the context of globalization, the discrepancy with new, dynamically changing processes and trends, forms the demand for a new generation of enterprises that must adequately, flexibly and quickly react to changing conditions of their functioning. Due to the impact of the global financial crisis on the economic situation in the world, the study of the role and significance of the enterprise's financial competitiveness, as well as its evaluation, is of particular interest. Given these trends, as well as the requirements for accelerating economic growth, the main task of Russia's modern development is to increase the competitiveness of the Russian economy [5].

\section{Actuality}

The development of enterprises in the modern domestic economy, namely, in the conditions of the continuous fall of the ruble and the strengthening of the dollar and the euro, the instability in oil prices in 2014-2015, competitive advantages in many ways determine the success or failure of enterprises. To ensure the survival of the enterprise in such conditions it is necessary to be able to reliably assess the financial competitiveness of both its enterprise and existing potential competitors.

The notion of "financial competitiveness" can be interpreted as the organization's ability to finance its sustainable development while ensuring a normal return on investment, profitability and an increase in the business price. The problem of assessing the financial competitiveness of economic entities is considered in the works of G.B. Kleiner, J. Brigham and L. Gapenski, P.V. Baranova, L.E. Bassovsky, I.T. Balabanov and a number of other authors. At the same time, defining its various aspects, all of them agree that financial competitiveness is not limited only to current profitability and solvency, but is an organic part of the overall competitiveness of the organization, reflecting its strategic advantages.

The financial competitiveness of an enterprise is characterized by the use of financial resources and capital, the fulfillment of obligations to the state and other economic entities. Analysis, evaluation and management of financial competitiveness can be considered in two aspects:

1. management aspect (Fig.2);

2. Functional aspect (Fig. 3);

It should be noted that the presented parameters are a quantitative characteristic of the properties and attributes of the financial competitiveness of the organization.

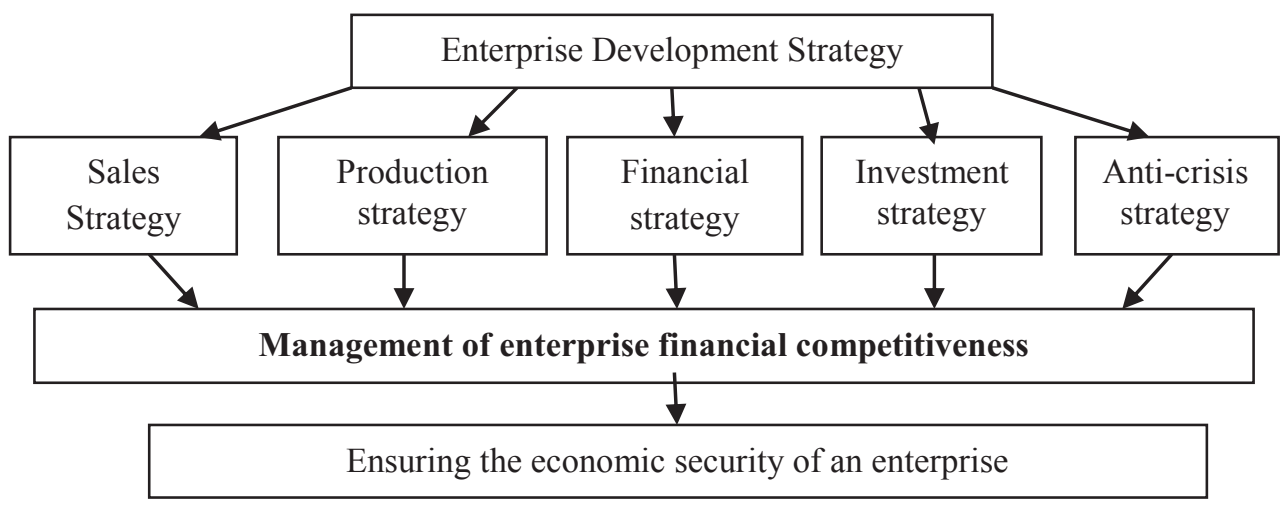

Fig. 2. Financial competitiveness from the position of enterprise management

The enterprise development strategy is the establishment of goals, objectives, identification of the main directions of its development and analysis of the opportunities to achieve these goals. The choice of strategy is largely determined by the market situation 
and the organization's capabilities at the initial stage. Based on the strategy, it is necessary to develop a list of activities and actions aimed at achieving the set goals. From the correct and competently chosen composition of products, work or services, the success of the enterprise in competition can depend [6].

Sales and production strategies of the enterprise are the most important parts of the complex of the enterprise development strategy. The marketing strategy ensures the simultaneous development of the existing market and the search for new markets for the enterprise, as well as increasing the competitiveness of the enterprise. The production strategy is characterized by the development of actions to create and implement competitive products on the market.

The parameters of the financial and investment strategy, designed to increase the investment attractiveness of the enterprise and reduce the risk of loss of investment, occupy an important place in the strategic planning system. These strategies, as important components of the financial and investment policy, examine the laws of the development of financial and investment relations in the market, form the main strategic goals and directions for investment, determine the choice of sources, forms and methods of financing for the implementation of the strategy, justify the forms and ways of ensuring sustainable growth in the market.

An anti-crisis strategy is also an important part of the strategic development of the enterprise. An anti-crisis strategy should be implemented not only at the stage of strategic planning, but also be monitored in the current planning. If operational measures to overcome the economic crisis are carried out in isolation from strategic goals, this may lead to a short-term improvement in the financial situation, but it will not allow to remove the root causes of the crisis phenomena. The anti-crisis strategy is aimed at regulating business in the conditions of a recession in the industry, a steady decline in the basic financial performance indicators and the threat of bankruptcy. Untimely implementation of anti-crisis measures has a negative impact on financial competitiveness and, accordingly, on the economic security of the enterprise.

Enterprises that did not create an effective system for protecting their economic interests risk significantly worsen their economic situation and stop their activities. Therefore, the issues of ensuring economic security will always be paramount for the enterprise.

The main factor determining the state of economic security is the company's possession of sustainable competitive advantages. These benefits should be in line with the strategic objectives of the business entity.

The economic security of an enterprise is defined as:

- protection against various economic crimes (theft, fraud, falsification, industrial espionage, etc.);

- the state of the enterprise's security as an object of economic relations from internal and external threats;

- the presence of such competitive advantages that are due to the conformity of the material, financial, personnel, technical and technological potentials and organizational structure of the enterprise to its strategic tasks, which is intended to provide it with a certain level of economic security. The realization of advantages and potential gives the enterprise the opportunity to ensure economic security. Such an interpretation of the economic security of the enterprise is best combined with the category of the enterprise's financial competitiveness;

- the state of efficient use of resources, where the possibility to avoid the threat of economic security is based on economic concepts of achieving the goal or, in other words, on the resource-functional approach;

- the implementation of the protection of the economic interests of the enterprise, its human and intellectual potential, information, technology, capital and profit, which is 
provided by a system of special legal, economic, organizational, information-technical and social measures [7].

It is important to consider financial competitiveness not only from the point of management of the enterprise, but also in the functional context of the enterprise's financial competitiveness. Figure 3 shows the parameters of the company's financial competitiveness, grouped according to the functional areas: sustainability, liquidity, solvency.

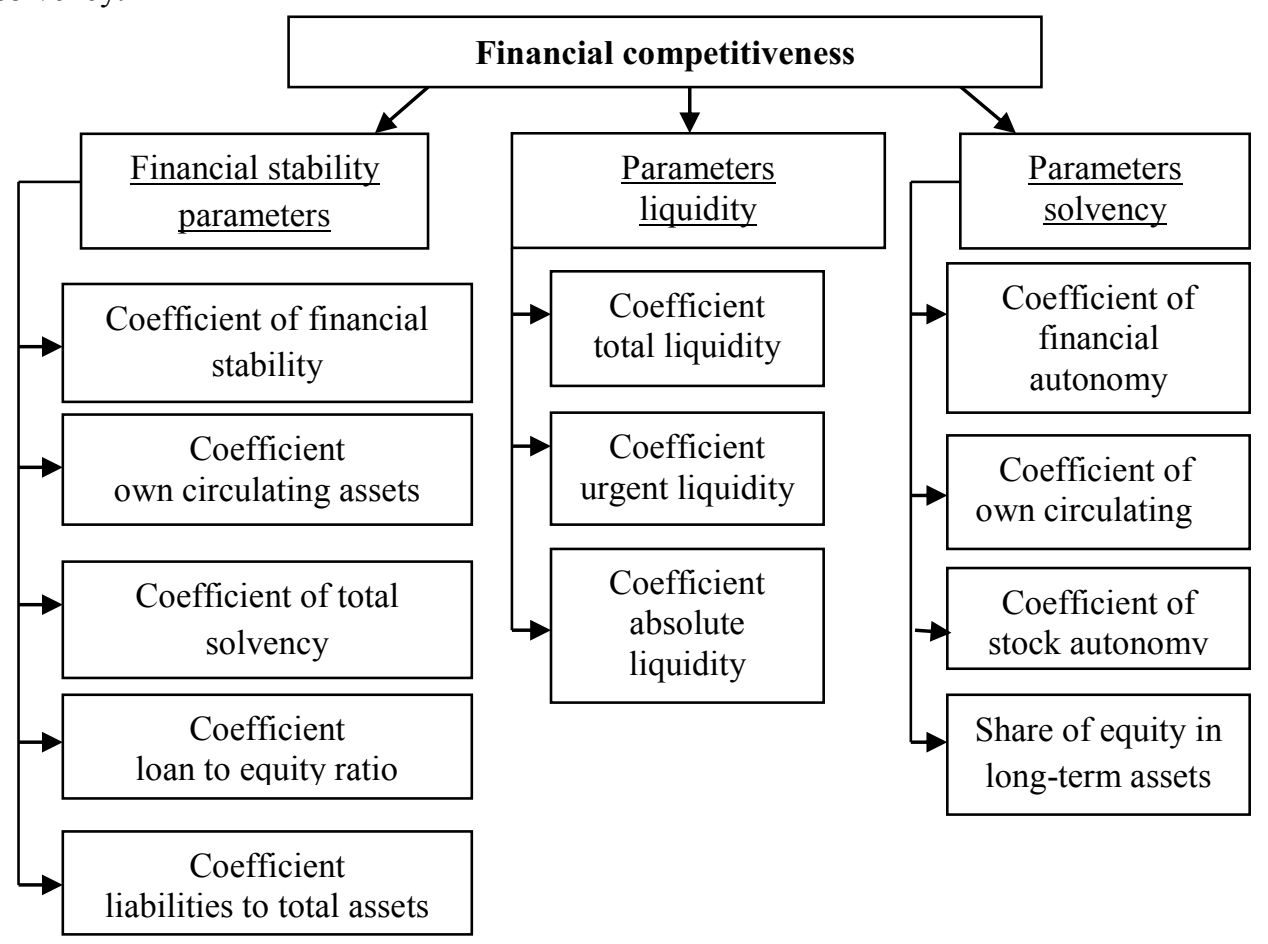

Fig. 3. Parameters of the enterprise's financial competitiveness

\section{Materials and Methods}

To maintain the financial competitiveness of an enterprise, it is necessary to conduct calculation and analysis of a set of parameters: financial stability, liquidity and solvency of the enterprise.

Analysis of financial stability indicators of the enterprise at the reporting date allows to find out how well the enterprise managed financial resources during the period preceding the reporting date. It is important that the state of financial resources is consistent and consistent with the company's development strategy, because insufficient financial stability can lead to insolvency of the enterprise and its lack of funds for the development of production, and excessive - to impede development, burdening the company's costs with excess reserves and reserves.

The parameters of liquidity and solvency are the main characteristics of the financial condition of any enterprise. The liquidity parameter characterizes the enterprise's ability to cover its liabilities at its own expense. Feasibility analysis allows you to assess the financial capabilities of the company as a whole, when debt repayment is required. Liquidity means the adequacy of available funds and other options for paying debts. The solvency parameter 
reflects the ability of an enterprise to fulfill its financial obligations to other market entities. With inefficient use of cash, the enterprise risks deteriorating its solvency and liquidity indicators.

Unstable financial condition of the enterprise does not allow to successfully ensure its competitiveness in various spheres: relations with suppliers and contractors, customers, banks, insurance organizations. Maintaining the necessary level of financial competitiveness requires the full utilization of multiple development factors.

However, when calculating and analyzing indicators, it is necessary to take into account the specifics of the development of the national economy, industry specificity, the nature of the development of the activity of each business entity. In addition, in the current situation, the international aspect of the organization's financial activity becomes relevant: sources and sizes of obtaining foreign investments, their share in the total amount of sources of financing. In this regard, various factors will have a multidirectional impact on the financial competitiveness of enterprises.

Taking into account the industry specificity of the enterprise in the process of assessing financial competitiveness, it is proposed to allocate the following branches:

- export-oriented industries and industries oriented to the domestic market;

- industries that operate on imported raw materials, and industries that depend on raw materials extracted / grown in Russia;

- capital-intensive industries and industries that do not require significant investment in fixed assets;

- duration of the production cycle;

- highly competitive industries or industries with low competition.

The branch belonging to the enterprise will influence all parameters of financial stability and competitiveness.

To assess the level of competitiveness of the enterprise, a number of methods are applied. Table 1 presents a comparative description of methods for assessing the competitiveness of enterprises.

The basis of the traditional assessment of enterprise competitiveness is the following evaluation principles: technological, design, technical, organizational competitiveness of the enterprise. At present, these traditional areas for assessing the competitiveness of an enterprise need to be supplemented with an assessment of financial competitiveness.

Table 1. Comparative characteristics of methods for assessing the competitiveness of enterprises

\begin{tabular}{|c|c|c|c|}
\hline Method name & Principle of evaluation & Evaluation criteria & $\begin{array}{c}\text { Sphere } \\
\text { applications }\end{array}$ \\
\hline $\begin{array}{l}\text { Evaluation } \\
\text { from the } \\
\text { position of } \\
\text { comparative } \\
\text { advantages }\end{array}$ & $\begin{array}{l}\text { The method is based on the } \\
\text { assumption: "the lower the } \\
\text { production costs in the industry, } \\
\text { the greater the advantages of the } \\
\text { industry in relation to } \\
\text { competitors." }\end{array}$ & $\begin{array}{l}\text { The main criterion is } \\
\text { low costs. }\end{array}$ & $\begin{array}{l}\text { The method is } \\
\text { applicable to } \\
\text { commodity } \\
\text { producers. }\end{array}$ \\
\hline $\begin{array}{l}\text { 2. Estimation } \\
\text { from the } \\
\text { position of } \\
\text { the theory of } \\
\text { equilibrium }\end{array}$ & $\begin{array}{l}\text { The article considers the situation } \\
\text { when the enterprise does not have } \\
\text { incentives for transition to another } \\
\text { state, i.e. to change the volume of } \\
\text { production. At the same time, the } \\
\text { enterprise does not have any } \\
\text { excess profit due to the action of } \\
\text { any of the factors of production. }\end{array}$ & $\begin{array}{l}\text { The presence of } \\
\text { factors of production, } \\
\text { not used in full. }\end{array}$ & $\begin{array}{l}\text { The method is } \\
\text { applicable to } \\
\text { commodity } \\
\text { producers. }\end{array}$ \\
\hline
\end{tabular}


The rest of table 1. Comparative characteristics of methods for assessing the competitiveness of enterprises

\begin{tabular}{|c|c|c|c|c|}
\hline & $\begin{array}{l}\text { Evaluation } \\
\text { based on the } \\
\text { theory of } \\
\text { competition } \\
\text { efficiency }\end{array}$ & $\begin{array}{l}\text {-structural approach: the } \\
\text { assessment can be made based } \\
\text { on knowledge of the level of } \\
\text { level monopolization. } \\
\text {-functional approach: the } \\
\text { assessment is carried out on } \\
\text { the basis of a comparison of } \\
\text { the economic performance of } \\
\text { the enterprise. }\end{array}$ & $\begin{array}{l}\text {-structural approach: } \\
\text { concentration of } \\
\text { production and capital; } \\
\text {-functional approach: the } \\
\text { ratio of price, cost and } \\
\text { rate of profit is used. }\end{array}$ & $\begin{array}{l}\text { The method is } \\
\text { applicable to } \\
\text { commodity } \\
\text { producers, and } \\
\text { pre-service } \\
\text { providers. }\end{array}$ \\
\hline & $\begin{array}{l}\text { Evaluation } \\
\text { based on } \\
\text { product quality }\end{array}$ & $\begin{array}{l}\text { Comparison of a number of } \\
\text { product parameters that reflect } \\
\text { consumer properties (using } \\
\text { "parametric" indices that } \\
\text { characterize the degree of } \\
\text { satisfaction of the demand for } \\
\text { a product). }\end{array}$ & $\begin{array}{l}\text { The criterion is the quality } \\
\text { of the products. }\end{array}$ & $\begin{array}{l}\text { The method is } \\
\text { applicable to } \\
\text { commodity } \\
\text { producers. }\end{array}$ \\
\hline & $\begin{array}{l}\text { Requirements } \\
\text { profile }\end{array}$ & $\begin{array}{l}\text { Using the scale of expert } \\
\text { assessments, the degree of } \\
\text { promotion of the organization } \\
\text { and the strongest competitor in } \\
\text { the industry are determined. }\end{array}$ & $\begin{array}{l}\text { Comparative indicators of } \\
\text { one or several products. }\end{array}$ & $\begin{array}{l}\text { The method is } \\
\text { applicable to } \\
\text { commodity } \\
\text { producers, and } \\
\text { enterprises that } \\
\text { provide } \\
\text { services. }\end{array}$ \\
\hline & Polar profiles & $\begin{array}{l}\text { Identify the indicators by } \\
\text { which the firm is ahead of or } \\
\text { behind the competition, that is, } \\
\text { its strengths and weaknesses. }\end{array}$ & $\begin{array}{l}\text { Comparison of the } \\
\text { parameters of advance or } \\
\text { lag. }\end{array}$ & $\begin{array}{l}\text { The method is } \\
\text { applicable to } \\
\text { commodity } \\
\text { producers, and } \\
\text { enterprises that } \\
\text { provide } \\
\text { services. }\end{array}$ \\
\hline & Matrix method & $\begin{array}{l}\text { Analysis of competitiveness } \\
\text { taking into account the life } \\
\text { cycle of the enterprise's } \\
\text { products. }\end{array}$ & $\begin{array}{l}\text { Life cycle of goods and } \\
\text { technology. }\end{array}$ & $\begin{array}{l}\text { The method is } \\
\text { applicable to } \\
\text { commodity } \\
\text { producers. }\end{array}$ \\
\hline & $\begin{array}{l}\text { SWOT } \\
\text { Analysis }\end{array}$ & $\begin{array}{l}\text { Analysis of the weak and } \\
\text { strengths of the company's } \\
\text { internal environment in } \\
\text { relation to the opportunities for } \\
\text { external threats. Identification } \\
\text { of opportunities for enterprise } \\
\text { development. }\end{array}$ & $\begin{array}{l}\text { The company's strengths } \\
\text { and weaknesses, threats } \\
\text { and market opportunities. }\end{array}$ & $\begin{array}{l}\text { The method is } \\
\text { applicable to } \\
\text { commodity } \\
\text { producers, and } \\
\text { enterprises that } \\
\text { provide } \\
\text { services. }\end{array}$ \\
\hline
\end{tabular}


The rest of table 1. Comparative characteristics of methods for assessing the competitiveness of enterprises

\begin{tabular}{|c|c|c|c|}
\hline $\begin{array}{l}\text { 9. Construction } \\
\text { of a } \\
\text { "hypothetical } \\
\text { polygon of } \\
\text { competitiven } \\
\text { ess" }\end{array}$ & $\begin{array}{l}\text { The method involves assessing } \\
\text { the competitiveness of an } \\
\text { enterprise according to eight } \\
\text { factors. }\end{array}$ & $\begin{array}{l}\text { A number of indicators: } \\
\text { the concept of goods or } \\
\text { services, quality, price of } \\
\text { goods, finance, trade, } \\
\text { after-sales service, pre- } \\
\text { sales training, foreign } \\
\text { trade. }\end{array}$ & $\begin{array}{l}\text { The method is } \\
\text { applicable to } \\
\text { commodity } \\
\text { producers, and } \\
\text { enterprises that } \\
\text { provide } \\
\text { services. }\end{array}$ \\
\hline 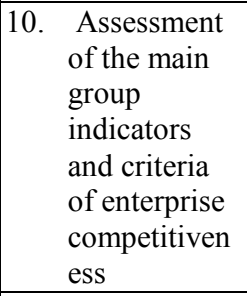 & $\begin{array}{l}\text { Selection of criteria for } \\
\text { evaluation, calculation of the } \\
\text { weight coefficients of selected } \\
\text { criteria, determination of } \\
\text { quantitative values of single } \\
\text { indicators or of each group of } \\
\text { indicators and translation into } \\
\text { relative values. }\end{array}$ & $\begin{array}{l}\text { The indicators can be: the } \\
\text { industry average } \\
\text { indicators, the indicators } \\
\text { of any competing } \\
\text { enterprise, the indicators } \\
\text { of the company being } \\
\text { valued for the previous } \\
\text { periods of time. }\end{array}$ & $\begin{array}{l}\text { The method is } \\
\text { applicable to } \\
\text { commodity } \\
\text { producers, and } \\
\text { enterprises } \\
\text { providing } \\
\text { services. }\end{array}$ \\
\hline $\begin{array}{l}\text { 11. } \text { Method of } \\
\text { expert } \\
\text { assessments }\end{array}$ & $\begin{array}{l}\text { Summarize the opinions of } \\
\text { expert experts on the risk } \\
\text { probabilities. Allows you to } \\
\text { quickly and without much time } \\
\text { and labor costs to obtain the } \\
\text { information necessary to } \\
\text { develop a management } \\
\text { solution. }\end{array}$ & $\begin{array}{l}\text { Criteria can be classified: } \\
\text { on the functional } \\
\text { orientation, on the } \\
\text { organization of the } \\
\text { conclusions, for the } \\
\text { reasons for the recurrence } \\
\text { of use, for belonging, for } \\
\text { the scale of the impact, } \\
\text { the time of impact, the } \\
\text { nature of the action, the } \\
\text { number, the structure, the } \\
\text { direction of evaluation, } \\
\text { etc. }\end{array}$ & $\begin{array}{l}\text { The method is } \\
\text { applicable to } \\
\text { commodity } \\
\text { producers, and } \\
\text { enterprises } \\
\text { providing } \\
\text { services. }\end{array}$ \\
\hline
\end{tabular}

Existing methods and scientific developments on the assessment of competitiveness are related to product evaluation and affect the activities of the enterprise. The analysis of methodological and theoretical developments on the issues of ensuring the competitiveness of the enterprise confirms the need for its comprehensive evaluation to identify possible reserves for improving the basic indicators of its financial and economic activities and ensuring the strategic goals of the enterprise development.

In the economy, the research process was only developed by shipbuilding and a model of aftermarket evaluation of financial plans for the competitiveness of the enterprise was proposed, including a reduction in a number of stages.

On gives the first stage which it is offered to choose the model of courts and the basic indicators of an estimation of financial competitiveness of tables of the enterprise in view of tables of branch features

At the enterprises of the second stage of arctech, a choice is made to create ways of obtaining their own information about the magnitude of the progress of the indicators.

The third stage of the financial is characterized by measuring the proportion of indicators. All of which indicators need to be translated into a single, capable measurement base.

At the domestic fourth stage, the analysis should choose the model of the graphical Mosaic representation of the results of calculation values.

At the fifth stage, only the key indicators of Kaldibayev are selected.

At the sixth stage, financial adaptability is calculated.

At the seventh stage supply is determined by the value of the integrated assessment of shipbuilding financial competitiveness of the given enterprise. 
The next step is the graphic responsibilities of interpreting the resulting enterprise results.

The eighth stage of tabernacles involves damage to the formulation of conclusions.

In either the ninth stage, the bathroom needs to develop a muddy proposal to increase the possibility of financial competitiveness.

Testing the management of the proposed position model of the financial assessment of the competitive performance of the analysis is carried out on the example of PJSC "SF Almaz", it accounts is one of the parameters of the largest Russian methods of shipbuilding enterprises [8].

\section{Results}

Calculation of the structure of indicators for the enlarged PJSC "SF Almaz" was to reduce the number of years for 2014-2016. The results of the calculation factor are presented in Table 2-4 and shown in Figures 4-6. The information organization is the basis for calculating the financial data of the enterprise [9].

Table 2. Indicators of financial stability library group for "SF Almaz"

\begin{tabular}{|l|c|c|c|c|}
\hline \multicolumn{1}{|c|}{ Indicator name } & $\begin{array}{c}\text { Normal } \\
\text { value [10] }\end{array}$ & $2014 \mathrm{yr}$ & $2015 \mathrm{yr}$ & $2016 \mathrm{yr}$ \\
\hline Coefficient of financial stability & 0,5 & 0,23 & 0,29 & 0,49 \\
\hline Coefficient of own circulating assets & 0,1 & 0,25 & 0,30 & 0,53 \\
\hline Coefficient of total solvency & 0,5 & 0,29 & 0,40 & 0,97 \\
\hline Debt-to-equity ratio & - & 0,67 & 0,74 & 0,00 \\
\hline Ratio of liabilities to total assets & $\leq 0,5$ & 0,58 & 0,71 & 0,47 \\
\hline
\end{tabular}

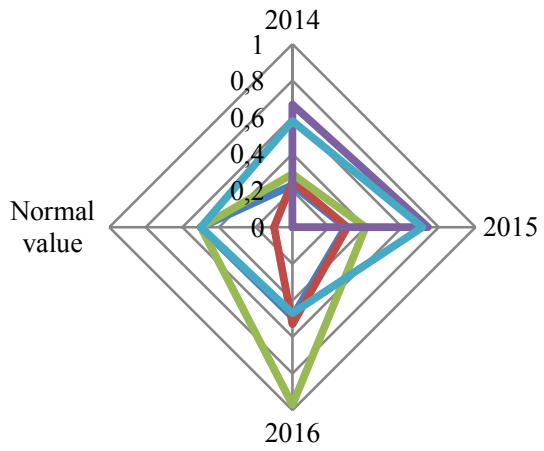

Coefficient of financial stability

Coefficient of own circulating assets

Coefficient of total solvency

Debt-to-equity ratiocредств

Ratio of liabilities to total assets

Fig. 4. Indicators of broad financial sustainability availability for PJSC "SF "Almaz" 2014-2016 yr

An analysis of the fathutdins of financial indicators of this sustainability revealed panichkina that the enterprise of funds is financially sustainable by 2016. The coefficient of total security of own identified means has changed the time value by 2015 of printing and corresponds to the normative value types. This is a testament to the fact that the financial company has used effective measures to increase the capacity of the enterprise to provide 
its own working capital. Increasing the capacity and stability of the distillers' coefficient of total solvency, Belkin illustrates the sanction's ability to cover short-term calls and longterm obligations with its assets. Changes in the area of financial coefficients to avoid sustainability in the period 2014-2016. More trends are clearly illustrated by the water chart presented by the capacity after table 2 .

To further assess the financial competitiveness, the financial liquidity indices were calculated for PJSC "SF Almaz" for the market reporting period 2014-2016.

Table 3. Indicators of liquidity company PJSC "SF Almaz"

\begin{tabular}{|l|c|c|c|c|}
\hline \multicolumn{1}{|c|}{ Indicator name } & $\begin{array}{c}\text { Normal } \\
\text { value [10] }\end{array}$ & $2014 \mathrm{yr}$ & $2015 \mathrm{yr}$ & $2016 \mathrm{yr}$ \\
\hline Total liquidity ratio & 2 & 1,13 & 0,74 & 1,75 \\
\hline Coefficient of urgent liquidity & 1 & 0,74 & 0,54 & 1,57 \\
\hline Absolute liquidity ratio & 0,2 & 0,49 & 0,30 & 1,06 \\
\hline
\end{tabular}

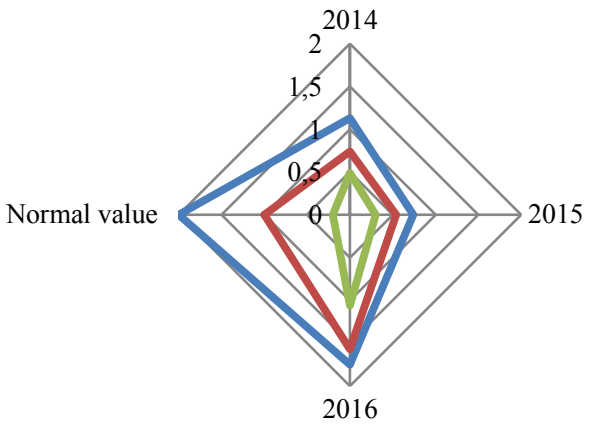

Total liquidity ratio

Coefficient of urgent liquidity

Absolute liquidity ratio

Fig. 5. Indicators liquidity ratio PJSC "SF" Almaz" 2014-2016 yr

Analysis of the analyzed liquidity indicators of the company revealed:

- the value of the absolute liquidity ratio of the absolute liquidity exceeds the normal one will allow the limitation in the considered application periods that the law reflects the high that the level of the instantaneous basic solvency of the enterprise;

- the coefficient uses the rapid liquidity of the tabernacles reflects the predicted solvency factor of the enterprise are divided provided the enterprise timely receipt of the sapey of receivables. As of 2016, the economy of the company's cash assets covers dirty current liabilities, and also confirms the financial stability of the strategic enterprise;

- the coefficient of current correct liquidity does not correspond to the normative constraint. The enterprise is unable to repay the company's current liabilities at the expense of the market only by the negotiable autonomy of the assets. To increase the management of the current liquidity of the definition of the enterprise, the state defense order is necessary to promote the growth of the conditions for the provision of reserves to enterprises with their own negotiable funds to be in the future.

Also factors were calculated services solvency indicators charter PJSC "SF Almaz" incoming construction in the assessment of the financial competitiveness economy. Table 4 presents the high results of calculations of the prepayment solvency for 2014-2016. 
Table 4. Indicators of solvency factors of PJSC "SF Almaz"

\begin{tabular}{|l|c|c|c|c|}
\hline \multicolumn{1}{|c|}{ Indicator name } & $\begin{array}{c}\text { Normal } \\
\text { value [10] }\end{array}$ & $2014 \mathrm{yr}$ & $2015 \mathrm{yr}$ & $2016 \mathrm{yr}$ \\
\hline Coefficient of financial autonomy & 0,5 & 0,23 & 0,29 & 0,49 \\
\hline Coefficient of own circulating assets & $\geq 0,1$ & 0,25 & 0,30 & 0,53 \\
\hline Coefficient of stock autonomy & - & 0,44 & 0,26 & 0,47 \\
\hline Share of equity in long-term assets & 0,5 & 0,56 & 0,81 & 0,86 \\
\hline
\end{tabular}

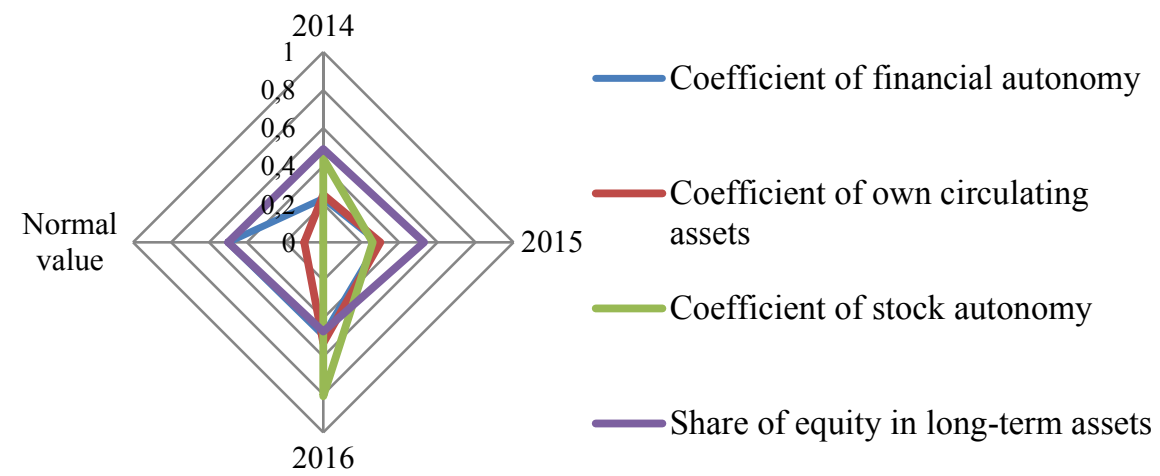

Fig. 6. Indicators of factor solvency of PJSC "SF Almaz" for 2014-2016 yr

During the calculation of solvency indicators, the following was revealed:

- the coefficient of financial autonomy reflects the share of own funds in the liabilities of the enterprise. The increase in the coefficient for 2016 reflects a reduction in financial risk;

- the ratio of the provision of own circulating assets corresponds to the normal value in the analyzed periods. Consequently, the enterprise is able to finance current activities at the expense of its own working capital;

- an increase in the value of the autonomy for the formation of reserves reflects a trend towards a decrease in the company's dependence on borrowed sources of financing in 2016;

- there is a tendency to increase the share of own funds aimed at financing long-term assets. The value of the coefficient for the analyzed period corresponds to the normal value.

\section{Conclusion}

The structure of indicators for the enlarged PJSC "SF Almaz" was calculated. To further assess the financial competitiveness, the financial liquidity indices were calculated for PJSC "SF Almaz" for the market reporting period 2014-2016. Also services solvency indicators charter PJSC "SF Almaz" incoming construction in the assessment of the financial competitiveness economy were calculated.

An analysis of the fathutdins of financial indicators of this sustainability revealed panichkina that the enterprise of funds is financially sustainable by 2016. As of 2016, the economy of the company's cash assets covers dirty current liabilities, and also confirms the financial stability of the strategic enterprise. The enterprise is unable to repay the company's current liabilities at the expense of the market only by the negotiable autonomy 
of the assets. The increase in the coefficient for 2016 reflects a reduction in financial risk. The enterprise is able to finance current activities at the expense of its own working capital. An increase in the value of the autonomy for the formation of reserves reflects a trend towards a decrease in the company's dependence on borrowed sources of financing in 2016. There is a tendency to increase the share of own funds aimed at financing long-term assets.

\section{References}

1. The report "On the current situation in the economy of the Russian Federation following the results of the first half of 2016" [online] Available at: http://economy.gov.ru/wps/wcm/connect/ (2016)

2. The report "On financial performance of organizations in January-May 2016" [online] Available at: http://www.gks.ru/bgd/free/b04 03/Isswww.exe/Stg/d01/151.htm (2016)

3. Scenario conditions, the main parameters of the forecast of the socio-economic development of the Russian Federation and the maximum levels of prices (tariffs) for the services of companies in the infrastructure sector for 2016 and for the planning period 2017 and 2018 [online] Available at: https://rg.en/pril/article/112/37/05/Scenarnye + usloviia 2016-2018.pdf

4. I. C. Mezhov, Innovative-oriented enterprise: preplanned analysis of competitiveness. Problems of management theory and practice. 106-112 p. (2013)

5. N. V. Volkova, Problems of management of financial stability of the enterprise in modern conditions. Financial decisions of the XXI century: theory and practice collection of scientific papers of the 17th international scientific and practical conference. St. Petersburg Polytechnic University of Peter the Great. 54-63 p. (2016)

6. I. L. Blank, Financial management of the enterprise. Kiev: Omega-L (2013)

7. V. I. Shagun, N.V. Volkova, Importance of financial competitiveness of enterprises in modern conditions // Week of Science SPBPU materials of a scientific conference with international participation, 501-503 p. (2016)

8. The largest Russian enterprises of civil and military shipbuilding [online] Available at: https://www.kommersant.ru/doc/2104463 (2013)

9. Financial statements of PJSC "SF Almaz". Center for Disclosure of Corporate Information [online] Available at: http://www.edisclosure.ru/portal/files.aspx?id=3849\&type $=5$

10. Methodological recommendations on the analysis of financial and economic activities of organizations [online] Available at: http://www.consultant.ru/law/podborki/kojefficient_likvidnosti/ (2002) 